See discussions, stats, and author profiles for this publication at: https://www.researchgate.net/publication/328031915

Serum heme oxygenase $1(\mathrm{HO}-1)$, soluble FMS like tyrosine kinase (sFlt-1) level, and neonatal outcome in early onset, late onset preeclampsia, and normal pregnancy

Article in Hypertension in Pregnancy · October 2018

DOI: 10.1080/10641955.2018.1494187

14 authors, including:

Muhammad Ilham Aldika Akbar

Airlangga University

$$
\begin{aligned}
& \text { Rozi Aryananda } \\
& 9 \text { Publications } 2 \text { CITATIONS } \\
& \text { SEE PROFILE }
\end{aligned}
$$

SEE PROFILE

Nareswari Cininta

Dr Soetomo General Hospital

7 PUBLICATIONS 1 CITATION

Manggala Pasca Wardhana

Airlangga University

11 PUBLICATIONS 13 CITATIONS

SEE PROFILE

SEE PROFILE

Some of the authors of this publication are also working on these related projects:

SUMPUC View project

Fetal medicine View project 


\section{Hypertension in Pregnancy}

ISSN: 1064-1955 (Print) 1525-6065 (Online) Journal homepage: http://www.tandfonline.com/loi/ihip20

\section{Serum heme oxygenase 1 (HO-1), soluble FMS like tyrosine kinase (sFlt-1) level, and neonatal outcome in early onset, late onset preeclampsia, and normal pregnancy}

Muhammad Ilham Aldika Akbar, Mita Herdiyantini, Rozi Aditya Aryananda, Nareswari CIninta, Manggala Pasca Wardhana, Khanisyah Erza Gumilar, Budi Wicaksono, Ernawati, Agus Sulistyono, Aditiawarman, Hermanto Tri Joewono, Nadir Abdullah, Gustaaf Dekker, Erry Gumilar Dachlan \& Muhammad Dikman Angsar

To cite this article: Muhammad Ilham Aldika Akbar, Mita Herdiyantini, Rozi Aditya Aryananda, Nareswari CIninta, Manggala Pasca Wardhana, Khanisyah Erza Gumilar, Budi Wicaksono, Ernawati, Agus Sulistyono, Aditiawarman, Hermanto Tri Joewono, Nadir Abdullah, Gustaaf Dekker, Erry Gumilar Dachlan \& Muhammad Dikman Angsar (2018): Serum heme oxygenase 1 (HO-1), soluble FMS like tyrosine kinase (sFlt-1) level, and neonatal outcome in early onset, late onset preeclampsia, and normal pregnancy, Hypertension in Pregnancy, DOI: $10.1080 / 10641955.2018 .1494187$

To link to this article: https://doi.org/10.1080/10641955.2018.1494187

Published online: 02 Oct 2018.

Submit your article to this journal ¿

View Crossmark data ¿ 


\title{
Serum heme oxygenase 1 (HO-1), soluble FMS like tyrosine kinase (sFlt-1) level, and neonatal outcome in early onset, late onset preeclampsia, and normal pregnancy
}

\author{
Muhammad Ilham Aldika Akbara, Mita Herdiyantinia, Rozi Aditya Aryananda ${ }^{a}$, Nareswari Clninta ${ }^{a}$, \\ Manggala Pasca Wardhana a, Khanisyah Erza Gumilara, Budi Wicaksono ${ }^{a}$, Ernawatia, Agus Sulistyono ${ }^{a}$, \\ Aditiawarmana, Hermanto Tri Joewono ${ }^{a}$, Nadir Abdullaha, Gustaaf Dekker ${ }^{\mathrm{a}, \mathrm{b}}$, Erry Gumilar Dachlanª, \\ and Muhammad Dikman Angsar ${ }^{a}$
}

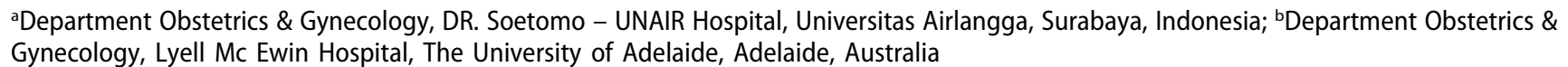

\begin{abstract}
Objective: To compare the level of serum heme oxygenase 1 (HO-1), soluble FMS like tyrosine kinase (sFlt-1), and neonatal outcome in early onset preeclampsia (EO-PE), late onset preeclampsia (LO-PE), and normal pregnancy (NP).

Methods: In this prospective observational case control study, HO-1 and sFlt-1 levels were measured in blood samples within $24 \mathrm{~h}$ of hospital admission. Preeclampsia cases were divided into two groups based on gestational age at delivery: EO-PE ( $<34$ weeks) and LO-PE ( $\geq 34$ weeks). A total of 45 patients were involved in this study.

Result: Maternal serum level of sFlt-1 was higher in EO-PE than LO-PE and NP groups (mean \pm SD; $14.50 \pm 17.12 \mathrm{ng} / \mathrm{ml}$ vs $5.20 \pm 6.69 \mathrm{ng} / \mathrm{ml}$ vs $2.72 \pm 1.2 \mathrm{ng} / \mathrm{ml}[p=0.020]$. Maternal serum level of HO-1 was not different between EO-PE, LO-PE, and NP groups $(p=0.681)$. Birthweights were significantly lower in the EO-PE group compared with the LO-PE and NP groups $(1580 \pm 536 \mathrm{~g}$ vs $2635 \pm 578 \mathrm{~g}$ vs $3010 \pm 371 \mathrm{~g}[p=0.000])$. The rate of small for gestational age infant $(26.7 \%$ vs $6.7 \%$ vs $0 \% ; p=0.046)$ and perinatal death (20\% vs 0 vs $0 ; p=0.037)$ was also significantly higher in EO-PE compared to LO-PE and NP. The maternal sFlt-1 level was negatively correlated with birthweight ( $p=0.006$; $C C=-0.445$ ).

Conclusion: This study did not find a correlation between maternal HO-1 levels and sFlt-1 levels. Maternal serum sFLt-1 levels in preeclampsia were higher in EO-PE and were associated with a worse perinatal outcome.
\end{abstract}

\section{ARTICLE HISTORY}

Received 26 December 2017

Accepted 24 June 2018

\section{KEYWORDS}

Heme oxygenase 1 (HO-1); soluble FMS like tyrosine kinase (sFlt-1); early onset preeclampsia; late onset preeclampsia; neonatal outcome; IUGR

\section{Introduction}

Preeclampsia is one of the leading causes of maternalfetal mortality and morbidity worldwide, in particularly in developing countries. It is characterized by new onset of hypertension and proteinuria after 20 weeks of gestation, and variable degrees of placental involvement as reflected in a higher rate of intra-uterine growth restriction (IUGR) and iatrogenic preterm birth (1). Hypertensive disorders of pregnancy complicate roughly $5-10 \%$ of pregnancies, and are responsible for about 25,000 maternal deaths in Africa, 22,000 in Asia, 3,800 in Latin America and Caribbean, and 150 in industrialized countries (2). Preeclampsia has been divided into early and late onset preeclampsia based on the onset of the disease, with 34-weeks gestational age at time of birth as cut-off. These two phenotypes of
PE have different clinical characteristics, most likely different key pathophysiological pathways involved, and also a different perinatal prognosis. Early onset preeclampsia (EO-PE) is mostly associated with more severe placental lesions, a higher rate of severe maternal clinical manifestations, fetal complications (IUGR, placental abruption), and worse perinatal prognosis compared to late onset preeclampsia (LO-PE) (3).

Research on the final common pathway leading to the characteristic endothelial cell dysfunction has recently focused on an imbalance between circulating angiogenic and anti-angiogenic factors following the landmark study of Karumanchi's group (4). The maternal syndrome preeclampsia develops because overexpression of circulating anti-angiogenic factors and low level of angiogenic factors causing endothelial dysfunction. The main pro-angiogenic factors

CONTACT Muhammad Ilham Aldika Akbar muhammad-i-a-a@fk.unair.ac.id $\otimes$ Dept Obstetrics \& Gynecology Soetomo Hospital, Faculty of Medicine Universitas Airlangga 
consist of Vascular Endothelial Growth Factor (VEGF) and Placental Growth Factor (PIGF), which regulate endovascular cytotrophoblast invasion, vascular growth in placenta, and maternal endothelial cell function. The main anti-angiogenic factors contributing to the maternal manifestations of preeclampsia are soluble FMS like tyrosine kinase 1 (sFlt-1) and soluble endoglin (sEng) (5). sFlt-1 is a VEGF-soluble receptor which acts as VEGF and PIGF antagonist by inhibiting angiogenic factor interaction with the endothelial VEGF receptor on the cell surface, inducing endothelial dysfunction $(5,6)$. Several studies have demonstrated that the imbalance between angiogenic and anti-angiogenic factor is significantly related, in time and severity, with clinical manifestation of preeclampsia. The PELICAN study has shown that a low level of PlGF can predict women with preeclampsia requiring delivery within 14 days (7-11).

One recent concept proposes that preeclampsia is caused by a failure of one of the key pregnancy protection systems during pregnancy, in addition to the aforementioned imbalance of angiogenic and anti-angiogenic factor. One of this early pregnancy protection systems known today is the heme oxygenase (HO)/carbon monoxide (CO) pathway $(12,13)$. HO is an endoplasmic reticulum enzyme which serves to degrade heme to produce biliverdin, free iron, and $\mathrm{CO}$ in proportional amount. $\mathrm{HO}$ has two isoforms: HO-1 and HO-2. In mammalian tissue, HO- 1 is induced by heme substrate, heavy metal, and other stimuli causing oxidative stress such as peroxynitrite, lipid, hypoxia, hyperoxia, ischemia, reperfusion, hyperthermia, and endotoxic shock (12). The potential mechanism by which HO-1 may exert a protective effect in normal pregnancy includes: (1) Regulation of uNK cell survival and angiogenic factors in the placental bed; fundamental in the spiral artery remodeling process, (2) protection of trophoblast cells from cellular destruction, (3) production of $\mathrm{CO}$ which is protective to pregnancy, (4) indirect stimulation of the production of VEGF and PIGF through CO, and (5) suppression of the production and secretion of antiangiogenic factors (sFlt- 1 and sEng) (13-17). These five mechanisms have been proposed to directly or indirectly protect the pregnancy and reduce the preeclampsia risk (12).

Maternal-neonatal clinical manifestations appear to differ between EO-PE and LO-PE. EO-PE is mostly associated with superficial cytotrophoblast invasion in the spiral arteries and as such often displays abnormal uterine Doppler flow patterns, impaired fetal growth, and poorer maternal-neonatal outcomes. On the other hand, LO-PE generally is mostly associated with normal uterine artery Doppler flow resistance indices, normal fetal growth, and no adverse perinatal outcome $(3,11)$.
We hypothesized that this discrepancy might be related to the difference levels of maternal serum HO1 versus sFlt-1. The aims of the current study were therefore to evaluate the differences in fetal outcomes (infant birth weight, birth weight centiles, 1- and 5 min-Apgar scores) between these two subtypes of preeclampsia, in relation to maternal serum levels of HO-1 and sFlt-1, in an Indonesian population.

\section{Methods}

This was an observational cross-sectional study. The study was conducted in Dr. Soetomo Hospital (the main tertiary referral hospital in East Java), and the University of Airlangga University Hospital between January and May 2016.

\section{Study population}

The study population consisted of all preeclampsia patients admitted during this 5-month period. Inclusion criteria were singleton pregnancy diagnosed with preeclampsia with severe features. None of these patients were smoking. Blood samples were taken consecutively from all preeclamptic patients fulfilling the inclusion criteria and a control group. Patients were divided into three groups: control, EO-PE and LO-PE groups, each consisting of 15 patients. The control group consisted of normal pregnant women between 20 and 40 weeks gestation, matched by gestational age with the preeclampsia subgroups. Early and late onset preeclampsia groups were defined using 34 weeks gestational age as cut-off. Preeclampsia was diagnosed in line with the International Society for the Study of Hypertension in Pregnancy (ISSHP) criteria (2014), i.e. new onset of hypertension (blood pressure greater than $140 / 90 \mathrm{mmHg}$ ) after 20 weeks gestation with the coexistence of one of the following: proteinuria, maternal organ dysfunction, and/or IUGR (18). After diagnosis of preeclampsia was confirmed, and the patient had been stabilized, blood samples were taken, typically within $2 \mathrm{~h}$ after hospitalization, and not more than $24 \mathrm{~h}$. The patients were followed until delivery, and neonatal outcomes (gestational age at delivery, birthweight, birthweight centile, Apgar score, oligohydramnios, Small Gestational Age (SGA), Intra Uterine Fetal Death (IUFD), NICU admission, and perinatal death) were recorded. Gestational age was recorded at delivery based on certain last menstrual periods or first-trimester ultrasound dating. Newborn birth weight was measured at delivery, and INTERGROWTH calculator determined the birth weight percentile. Oligohydramnions was 
determined by ultrasound using criteria: amniotic fluid index $<8 \mathrm{~cm}$ or single deepest pocket $<2 \mathrm{~cm}$. SGA was defined as a birth weight percentile $<10$. IUFD was diagnosed by loss of heart beat in $2 \mathrm{D}$, M-Mode or Doppler examination using ultrasound, in any stage of pregnancy. NICU admission was defined as a newborn need a special care in NICU, without considering the duration of care. Perinatal death was defined using WHO criteria as a fetal death in utero (stillbirth) above 20 weeks gestation until 7 days after delivery.

\section{Blood samples and assays}

A quantity of $15 \mathrm{ml}$ of blood sample was collected from untecubital vein into tube. Blood sample was left coagulated for $30 \mathrm{~min}$, then centrifuged $2400 \mathrm{~g}$ for $10 \mathrm{~min}$ before put into fresh tube and stored at $<20^{\circ} \mathrm{C}$ in refrigerator for later examination. Serum heme oxygenase 1 (HO-1) level was measured using HO-1 StressXpress ELISA Kit using quantitive sandwich enzyme immunoassay technique. While serum sFlt-1 level was measured using separate kit, Quantikine Human VEGF-R1 Kit with simple enzyme-linked immunosorbent assay (ELISA) methods. Laboratory staff completing the assays were blinded regarding the status of the patient (control versus preeclampsia).

Signed informed consent was obtained from all participating patients.
The ethical clearance of this study has been approved by Dr. Soetomo Medical Research Ethical Committee.

\section{Result}

\section{Clinical characteristics and risk factors}

The general characteristics and risk factors in every group are presented in Table 1. There were, as expected, significant differences among three groups in maternal age, gestational age during recruitment and delivery, and preexisting chronic hypertension. Preeclampsia groups tended to be older compared to normal control group in this study. Preexisting hypertension was more common in EO-PE group. Additional risk factors such as diabetes mellitus, renal disease, rheumatic disease, antiphospholipid syndrome, and history of familial preeclampsia were not found in any group.

\section{Maternal serum heme oxygenase-1 and sFlt-1 level}

This study found very similar maternal serum HO-1 level in the three subgroups ( $4.55 \pm 0.98$ vs $4.80 \pm 1.32$ vs $4.4 \pm 1.08, p=0.681$ ) (Table 2 , Figure 1 ). The level of sFlt-1 was higher in EO-PE compared with LO-PE and the control group $(14.50 \pm 17.12 \mathrm{ng} / \mathrm{ml}$ vs $5.20 \pm 6.69 \mathrm{ng} / \mathrm{ml}$ vs $2.72 \pm 1.2 \mathrm{ng} / \mathrm{ml} ; p=0.020)$. But there was no significant difference between maternal

Table 1. Characteristic and risk factors in early onset PE, late onset PE, and control groups.

\begin{tabular}{|c|c|c|c|c|}
\hline & Early onset preeclampsia & Late onset preeclampsia & Control & $\rho$ \\
\hline Maternal Age (years) & $32.94+5.66$ & $33.88+6.58$ & $28.9+6.0$ & $0.036^{*}$ \\
\hline Body Mass Index $\left(\mathrm{kg} / \mathrm{m}^{(2)}\right)$ & $28.22+5.68$ & $28.82+5.19$ & $25.56+4.92$ & 0.172 \\
\hline Chronic Hypertension & $18 \%$ & $0 \%$ & $0 \%$ & $0.027^{*}$ \\
\hline \multicolumn{5}{|l|}{ Parity } \\
\hline Primi & $43.8 \%$ & $12.5 \%$ & $28.6 \%$ & 0.208 \\
\hline Multi & $43.8 \%$ & $68.8 \%$ & $61.9 \%$ & \\
\hline Grande Multi & $12.5 \%$ & $18.8 \%$ & $9.5 \%$ & \\
\hline Obesity & $31.2 \%$ & $18.8 \%$ & $9.5 \%$ & 0.253 \\
\hline Previous PE & $0 \%$ & $12.5 \%$ & $0 \%$ & 0.095 \\
\hline IVF Pregnancy & $6.2 \%$ & $0 \%$ & $0 \%$ & 0.315 \\
\hline
\end{tabular}

${ }^{*} \rho<0.05$.

Table 2. Maternal serum level of HO, sFLT1, and neonatal outcome in early onset PE, late onset PE, and control groups.

\begin{tabular}{|c|c|c|c|c|}
\hline & Early onset preeclampsia & Late onset preeclampsia & Control & $\rho$ \\
\hline Gestational age at recruitment & $31.0+2.59$ & $36.83+1.85$ & $33.46+3.90$ & $0.001^{*}$ \\
\hline Gestational age at delivery & $32.67+1.303$ & $36.83+1.850$ & $38.23+1.103$ & $0.000^{*}$ \\
\hline Birthweight & $1580.33+536.93$ & $2635.83+578.28$ & $3010+371.69$ & $0.000^{*}$ \\
\hline Birthweight Percentile & $25.91+27.06$ & $33.13+22.31$ & $34.93+26.64$ & 0.654 \\
\hline Apgar score minutes 1 & $5.25+2.67$ & $6.33+1.87$ & $7.15+1.41$ & 0.047 \\
\hline Apgar score minutes 5 & $6.75+2.63$ & $7.75+1.01$ & $8.23+1.17$ & 0.069 \\
\hline Oligohydramnios & $2(13.3 \%)$ & 0 & 0 & 0.117 \\
\hline SGA $\left(P<10^{\text {th }}\right)$ & $4(26.7 \%)$ & $1(6.7 \%)$ & 0 & $0.046^{*}$ \\
\hline IUFD & $2(13.3 \%)$ & 0 & 0 & 0.117 \\
\hline NICU admission & $7(46.7 \%)$ & $5(33.3 \%)$ & $2(13.3 \%)$ & 0.088 \\
\hline Perinatal death & $3(20 \%)$ & 0 & 0 & $0.037^{*}$ \\
\hline $\mathrm{HO}$ & $4.55+0.98$ & $4.80+1.32$ & $4.4+1.08$ & 0.681 \\
\hline sFlt1 & $14.50+17.12$ & $5.20+6.69$ & $3.04+1.88$ & $0.023^{*}$ \\
\hline
\end{tabular}


Table 3. Correlation between maternal serum level of $\mathrm{HO}$, sFLT1, and neonatal outcome.

\begin{tabular}{llc}
\hline Variable & $P$ & Coefficient correlation \\
\hline HO - birthweight & 0.842 & -0.034 \\
HO - percentile birthweight & 0.215 & -0.209 \\
HO - Apgar score min 1 & 0.041 & -0.338 \\
HO - Apgar score min 5 & $0.035^{*}$ & -0.348 \\
sFlt1 - birthweight & $0.006^{*}$ & -0.445 \\
sFlt1 - Percentile birthweight & 0.085 & -0.287 \\
sFlt1 - Apgar score min 1 & 0.222 & -0.206 \\
sFlt1 - Apgar score min 5 & 0.273 & -0.185 \\
HO - sFlt1 & 0.240 & -0.198 \\
\hline
\end{tabular}

serum sFlt-1 in LO-PE and NP, as seen in Table 2 and Figure 2. Importantly, we did not find a significant correlation between maternal serum sFlt-1 and HO-1 level $(p=0.240)$.

\section{Neonatal outcome}

Gestational age at birth was, by definition, significantly different between EO-PE vs LO-PE vs control groups $(32.67+1.303$ vs $36.83+1.850$ vs $38.23+1.103$ weeks $)$, respectively. This was in conjunction with difference in infant birth weight, which was lower in EO-PE rather than LO-PE and control group $(1580 \pm 536$ vs $2635 \pm 578$ vs $3010 \pm 371 \mathrm{~g} ; p=0.000$ ). Regarding birthweight centiles, using the INTERGROWTH calculator, there was no difference in the mean birthweight centiles between the three groups $(25.91+27.06$ vs
$33.13+22.31$ vs $34.93+26.64 ; p=0.654)$. However, the rate of SGA infants (birthweight percentile $<10^{\text {th }}$ ) ( $26.7 \%$ vs $6.7 \%$ vs $0 \%$; $p=0.046)$ and perinatal mortality ( $20 \%$ vs 0 vs $0 ; p=0.037)$ were significantly higher in EO-PE than LO-PE and control group. Other parameters such as minute- 1 and minute- 5 Apgar scores, incidence of oligohydramnios, stillbirth, and admission to NICU showed no differences between the three groups (Table 2).

The maternal sFlt-1 level was negatively correlated with actual birthweight ( $p=0.006$; CC: -0.445$)$, while HO-1 levels had a negative correlation with the 5-min Apgar score ( $p=0.035$; CC: -0.348$)$ (Table 3$)$.

\section{Discussion}

This study found that the maternal serum level of HO-1 was quite similar in EO-PE vs LO-PE and vs normal control pregnant women, and the HO-1 levels did not show any correlation with sFlt-1 levels. Maternal HO-1 levels were not significantly correlated with any neonatal outcome, except the neonatal Apgar score (likely reflecting a coincidental finding).

In line with the existing literature, the maternal sFlt1 level in the EO-PE group was significantly higher than LO-PE and control group, while the sFlt-1 levels in the LO-PE group were not different when compared with the control group (Table 2) (19-21). This finding

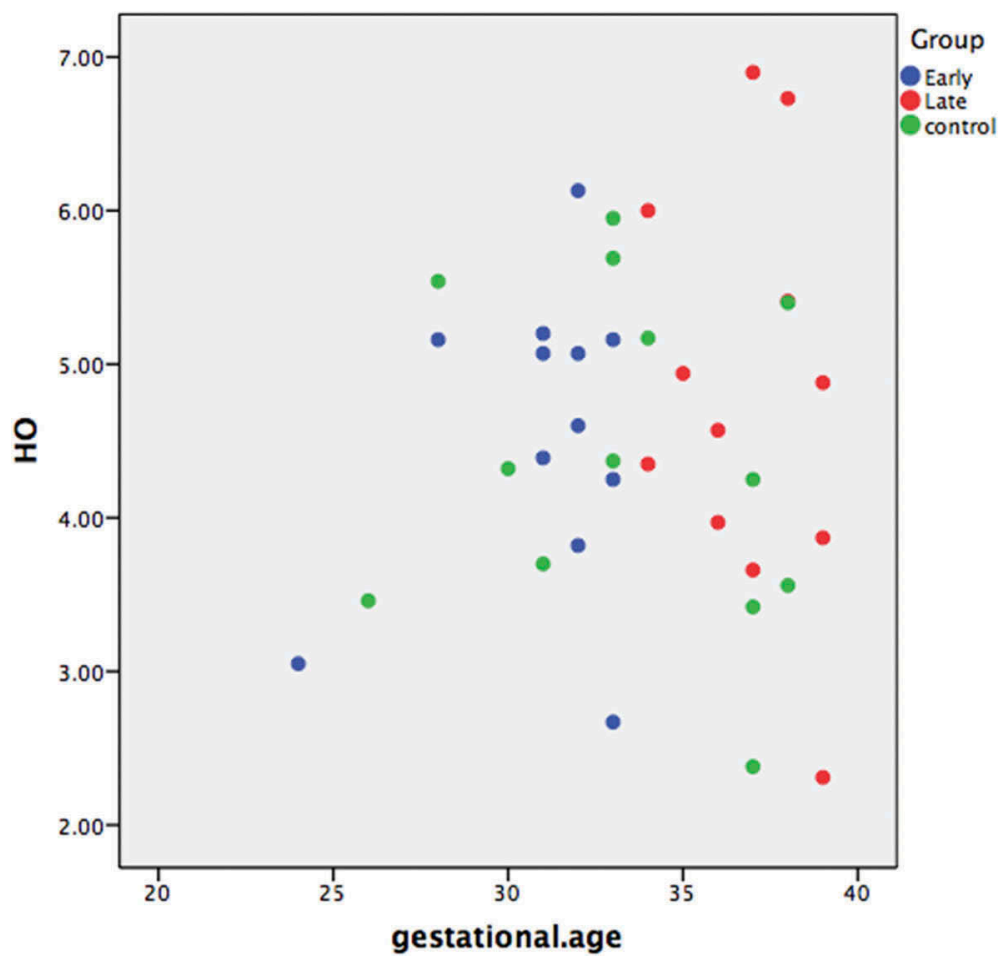

Figure 1. Plot distribution of maternal serum $\mathrm{HO}$ level in early onset $\mathrm{PE}$, late onset $\mathrm{PE}$, and control groups, based on gestational age. (Blue dot indicate EO-PE, red dot indicate LO-PE, and normal control groups as green dot). 


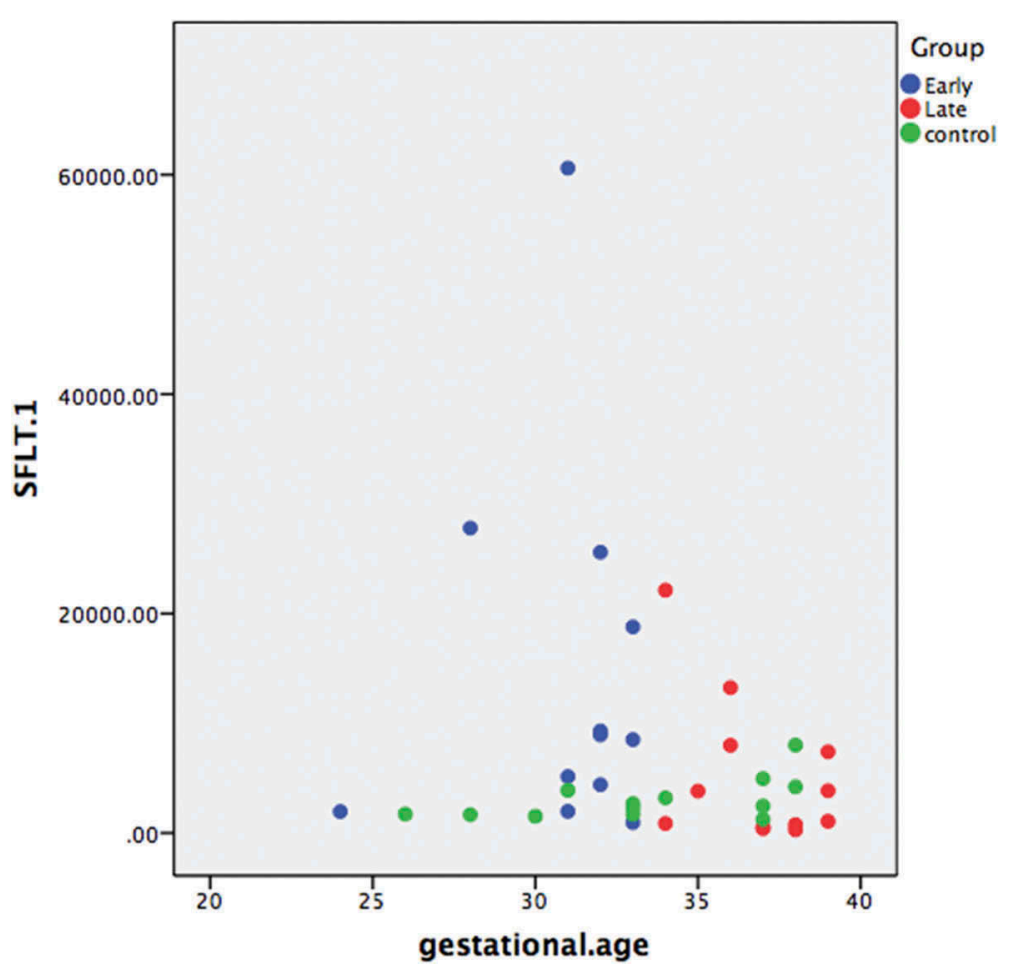

Figure 2. Plot distribution of maternal serum sFlt-1 level in early onset PE, late onset PE, and control groups, based on gestational age.

is in accordance with previous studies, showing the placental involvement/lesion in EO-PE, being minimal or absent in LO-PE. In terms of neonatal outcome, the maternal sFlt-1 level was significantly correlated with birthweight ( $p=0.006, \mathrm{CC}=-0.445)$.

Several studies have proposed that HO-1 is protective against preeclampsia by suppressing anti angiogenic factor activity, especially sFlt-1 and sEng. Previously, it has been shown that HO-1 deficiency in the placenta is associated with elevated sFlt-1 levels and preeclampsia itself $(12,17,22)$. However, the maternal serum HO-1 levels and its association with PE are still unclear, because various studies had different results. In the current study, we did not find any significant difference in maternal serum HO-1 levels between the three subgroups. This finding is in line with some studies $(23,24)$, but contradict others describing increased levels of serum HO-1 in preeclampsia groups (25-27). Vitoratos et al. were the first to study the relationship between maternal serum $\mathrm{HO}-1$ and preeclampsia, involving 31 pregnant women divided into Severe PE, Mild PE, and control groups, measured at 30-34 weeks. HO-1 serum levels were measured using assay kit (EKS-800, StressXpress, New York, USA) with ELISA methods. Inter-assay and intra-assay variability was less than $10 \%$. The severe PE group had significantly higher serum HO-1 levels compared to mild PE and normotensive groups. Maternal serum HO-1 levels were positively correlated with mean blood pressure (26). Erdemli HK et al. had similar results in their case control study involving 33 pregnant PE women with 43 normotensive pregnant women (samples taken at 27-34 weeks gestation). HO-1 serum levels were also measured using ELISA methods with available assay kit (Cusabio Biotech Co., Houston, USA. human hemeoxygenase 1, Lot no:N241161072), with intra-assay variability around $4 \%$. Serum HO-1 levels were significantly higher in PE group compared with the control group (76.7 vs $55.9 \mathrm{ng} / \mathrm{ml} ; p=0.006$ ), and a positive correlation was found between $\mathrm{HO}-1$ levels with presence sign of preeclampsia $(r=0.316 ; p=0.005)(25)$.

Karthikeyan et al. found no differences between serum HO-1 levels in their study involving $38 \mathrm{PE}$ pregnant women and 38 normotensive pregnant women, in line with our findings (24). Also Varol et al. found no significant differences in serum HO-1 levels between severe and mild PE (total 46 cases) in their study (23). Serum HO-1 levels in both studies were measured using ELISA methods with different assay kits (Stressgen, Ann Arbor vs Cusabio Biotech Co Ltd) $(23,24)$. The explanation for these divergent results is not clear, but may reflect differences in patient severity. In addition, although aforementioned papers used ELISA methods, different assay kits were used in these studies. However, importantly all these studies, including the current study agree on the fact that a lack 
of HO-1 (as measured in the peripheral circulation) is apparently not the main explanation for the increased maternal sFlt-1 levels.

The data of the current study and the aforementioned studies indicate that maternal serum HO-1 is not the main defense mechanism against oxidative stress in systemic circulation (28). Further research, in particularly longitudinal studies, will be required to arrive at a better understanding on how changes in placental HO-1 expression relate to the maternal the serum HO-1 level in normal and pathological pregnancies (25).

\section{Conclusion}

This study did not find any difference between maternal serum HO-1 level of EO-PE, LO-PE, and normal pregnancy. Serum HO-1 levels also did not show any correlation with fetal outcome. Serum sFlt-1 levels were higher level in EO-PE compared with LO-PE and normal pregnancies, and increased sFlt-1 were associated with a worse perinatal outcome.

\section{Declaration of interest}

The authors report no conflicts of interest.

\section{References}

1. Dekker G, Sibai B. Primary, secondary and tertiary prevention of preeclampsia. Lancet. 2001; 357: 20915. 10.1016/S0140-6736(00)03599-6

2. Hutcheon JA, Lisonkova S, Joseph KS. Epidemiology of pre-eclampsia and the other hypertensive disorders in pregnancy. Best Pract Res Clin Obstetrics Gynaecol. 2011; 25: 391-403. 10.1016/j.bpobgyn.2011.01.006

3. Valensise H, Vasapollo B, Gagliardi G, Novelli GP. Early and late preeclampsia: two different maternal hemodynamic states in the latent phase of the disease. Hypertension. 2008; 52: 873-80. 10.1161/ HYPERTENSIONAHA.108.117358

4. Maynard SE, Venkatesha S, Thadhani R, Karumanchi SA. Soluble FMS-like tyrosine kinase 1 and endothelial dysfunction in the pathogenesis of preeclampsia. Pediatr Res. 2005; 57: 1R-7R. 10.1203/01.PDR.0000159567.85157.B7

5. Karumanchi SA, Rana S, Taylor RN. Chapter 6: angiogenesis and Preeclampsia. In Taylor R, Roberts J, Cunningham F, Lindheimer M (eds), Chesley's hypertensive disorders in pregnancy. 4th edition. Elsevier, 2015

6. De Vivo A, Baviera G, Giordano D, Todarello G, Corrado F, D'anna R. EndoglinPlGF and sFlt-1 as markers for predicting preeclampsia. Acta Obstet Gynecol Scand. 2008; 87: 837-42. 10.1080/00016340802253759

7. Chappell LC, Duckworth S, Seed PT, Griffin M, Myers J, Mackillop L, et al. Diagnostic accuracy of placental growth factor in women with suspected preeclampsia: a prospective multicenter study. Circulation. 2013; 12819 : 2121-3110.1161/CIRCULATIONAHA.113.003215

8. Hagmann H, Thadhani R, Benzing T, Karumanchi SA, Stepan $\mathrm{H}$. The promise of angiogenic markers for the early diagnosis and prediction of preeclampsia. Clin Chem. 2012; 585: 837-4510.1373/clinchem.2011.169094

9. Ahmad S. Elevated placental soluble vascular endothelial growth factor receptor-1 inhibits angiogenesis in preeclampsia. Circ Res. 2004; 95: 884-91. 10.1161/01. RES.0000147365.86159.f5

10. Ramma W, Buhimschi IA, Zhao G, Dulay AT, Nayeri UA, Buhimschi CS, Ahmed A. The elevation in circulating anti-angiogenic factors is independent of markers of neutrophil activation in preeclampsia. Angiogenesis. 2012; 15: 333-40. 10.1007/s10456-012-9261-5

11. Crispi F, Domínguez C, Llurba E, Martín-Gallán P, Cabero L, Gratacós E. Placental angiogenic growth factors and uterine artery doppler findings for characterization of different subsets in preeclampsia and in isolated intrauterine growth restriction. Am J Obstet Gynecol. 2006; 195: 201-07. 10.1016/j.ajog.2006.01.014

12. Ahmed A, Ramma W. Unravelling the theories of preeclampsia: are the protective pathways the new paradigm?. Br J Pharmacol. 2015; 172: 1574-86. 10.1111/ bph.12977

13. Ahmed A, Rahman M, Zhang X, Acevedo CH, Nijjar S, Rushton I. et al. Induction of placental heme oxygenase- 1 is protective against TNF alpha-induced cytotoxicity and promotes vessel relaxation. Mol Med. 2000; 6: 391-409

14. Linzke N, Schumacher A, Woidacki K, Croy BA, Zenclussen AC. Carbon monoxide promotes proliferation of uterine natural killer cells and remodelling of spiral arteries in pregnant hypertensive heme oxygenase-1 mutant mice. Hypertension. 2014; 63: 580-88. 10.1161/HYPERTENSIONAHA.113.02403

15. Ahmed A. Heparin-binding angiogenic growth factors in pregnancy. Trophoblast Res. 1998; 10: 215-58

16. Zenclussen ML, Linzke N, Schumacher A, Fest S, Meyer N, Casalis PA, Zenclussen AC. Heme oxygenase- 1 is critically involved in placentation, spiral artery Remodelling, and blood pressure regulation during murine pregnancy. Front Pharmacol. 2015; 5Article 291: 110.3389/fphar.2014.00291

17. Cudmore M, Ahmad S, Al-Ani B, Fujisawa T, Coxall $\mathrm{H}$, Chudasama $\mathrm{K}$, et al. Negative regulation of soluble Flt-1 and soluble endoglin release by heme oxygenase1. Circulation. 2007; 115: 1789-97. 10.1161/ CIRCULATIONAHA.106.660134

18. Tranquilli AL, Dekker G, Magee L, Roberts J, Sibai BM, Steyn W, Zeeman GG, Brown MA. ISSHP. The classification, diagnosis and management of the hypertensive disorders of pregnancy: A revised statement from ISSHP. Pregnancy Hypertension. 2014; 4: 97-104. 10.1016/j.preghy.2014.02.001

19. Chaiworapongsa T, Romero R, Espinoza J, Bujold E, Mee Kim Y, Gonçalves LF, Gomez R, Edwin S. Evidence supporting a role for blockade of the vascular endothelial growth factor system in the pathophysiology of preeclampsia. Young Investigator Award. Am J Obstet Gynecol. 2004; 1906: 1541-47. 10.1016/j. ajog.2004.03.043 
20. Wikström A-K, Larsson A, Eriksson UJ, Nash P, NordénLindeberg S, Olovsson M. Placental growth factor and soluble FMS-like tyrosine kinase-1 in early-onset and late-onset preeclampsia. Obstet Gynecol. 2007; 1096: 1368-74. 10.1097/01.AOG.0000264552.85436.a1

21. Masuyama $H$, Segawa $T$, Sumida $Y$, Masumoto A, Inoue S, Akahori Y, Hiramatsu Y. Different profiles of circulating angiogenic factors and adipocytokines between early- and late-onset pre-eclampsia. BJOG. 2010; 117: 314-20. 10.1111/j.1471-0528.2010.02739.x

22. Miyagami S, Koide K, Sekizawa A, Ventura W, Yotsumoto J, Oishi S, Okai T. Physiological changes in the pattern of placental gene expression early in the first trimester. Reprod Sci. 2013; 20: 710-14. 10.1177/ 1933719112466309

23. Varol F, Uzunoglu R, Erbas H. Sut N, Sayin C. VEGFR-1, Bcl-2, and HO-1 ratios in pregnant women with hypertension. Clin Appl Thrombosis/Hemostasis. 2013; 21(3):1-4

24. Karthikeyan VJ, Lip GY, Baghdadi S, Lane DA, Beevers $\mathrm{DG}$, Blaan AD. Angiogenin and hemeoxygenase in pregnancy: influence of hypertension. Angiology. 2012; 63: 194-98.10.1177/0003319711410308

25. Erdemli HK, Yıldırımlar P, Alper TY, Kocabaş R, Salis $\mathrm{O}$, Bedir A. Increased serum heme oxygenase-1 levels as a diagnostic marker of oxidative stress in preeclampsia. Hypertens Pregnancy. 2014; 334: 488-97. 10.3109/ 10641955.2014.946613

26. Vitoratos N, Papakonstantinou K, Deliveliotou A, Economou E, Panoulis C, Hassiakos D, Creatsas GK. Antepartum and postpartum serum heme oxygenase-1 levels in preeclamptic and normotensive pregnant women. In Vivo. 2011; 25: 445-50

27. Wantania JJ, Homenta C, Kepel BJ. Relationship of heme oxygenase-1 (HO-1) level with onset and severity in normotensive pregnancy and severe preeclampsia. Bali Med J. 2016; 51: 118-2210.15562/ bmj.v5i1.267

28. Agarwal A, Mellado AA, Premkumar BJ, Shaman A, Gupta S. The effects of oxidative stress on female reproduction: a review. Reprod Biol Endocrinol. 2012; 10: 49 